\title{
BENTUK BATIK TULIS LASEM MOTIF KRECAK DI PERUSAHAAN BATIK TULIS LASEM SEKAR KENCANA
}

\author{
Qisthi Maghfiroh \\ Program Studi Desain Komunikasi Visual, Fakultas Bahasa dan Seni, Universitas Indraprasta PGRI \\ *corresponding author: Qisti Maghfiroh, qisthi.maghfiroh@gmail.com, Jakarta, Indonesia
}

\begin{abstract}
Abstrak. Seni kerajinan batik tulis Lasem merupakan salah satu identitas dari kota Lasem, Rembang. Lasem dijuluki sebagai "Tiongkok Kecil" karena merupakan kota awal pendaratan orang Tionghoa di tanah Jawa. Lasem sebagai salah satu sentra industri batik tulis di Indonesia mempunyai hasil batikan yang unik dan khas yang tidak dapat ditemui di daerah lain. Seni kerajinan batik tulis Lasem sulit berkembang disebabkan oleh perajin batik keturunan Tionghoa yang dianggap paling menguasi ilmu dan tradisi batik tulis Lasem, namun enggan untuk menularkan ilmunya kepada generasi muda yang bukan garis keturunannya. Penelitian ini berusaha menjelaskan bentuk seni kerajinan batik tulis Lasem motif krecak di perusahaan batik tulis Lasem Sekar Kencana di Desa Babagan Kecamatan Lasem Kabupaten Rembang. Metode pengumpulan data adalah wawancara, observasi dan dokumentasi. Validitas data menggunakan teknik triangulasi model Miles. Temuan: Bentuk seni kerajinan batik tulis Lasem motif krecak di perusahaan batik tulis Lasem Sekar Kencana di Desa Babagan Kecamatan Lasem Kabupaten Rembang memiliki keunikan pada motif yang dibuat sendiri oleh juragan dan merupakan akulturasi antara budayaan Cina dengan Jawa (keraton) dan atau dengan kebudayaan setempat (Lasem), serta mempertahankan warna-warna klasik khas Lasem dalam batik tulisnya.
\end{abstract}

Kata Kunci: seni kerajinan, batik tulis, Lasem

\begin{abstract}
Lasem batik craft art is one of the identities of the city of Lasem, Rembang. Lasem was nicknamed "Little China" because it was the town where the Chinese first landed on Java. Lasem, as one of the centers of the batik industry in Indonesia, has unique and distinctive batikan products that cannot be found in other regions. Lasem's handcrafted batik art is difficult to develop due to Chinese batik craftsmen who are considered to have the most knowledge of the knowledge and traditions of Lasem written batik, but are reluctant to pass on their knowledge to younger generations who are not of their lineage. This research tries to explain the art form of Lasem batik craft with krecak motif in the Lasem Sekar Kencana written batik company in Babagan Village, Lasem District, Rembang Regency. Data collection methods are interviews, observation and documentation. The validity of the data used the Miles model triangulation technique. Findings: The art form of Lasem batik craft with krecak motifs in the Lasem Sekar Kencana written batik company in Babagan Village, Lasem District, Rembang Regency is unique in motifs made by masters themselves and is an acculturation between Chinese and Javanese culture (the palace) and / or with local culture (Lasem), as well as retaining Lasem's classic colors in his written batik.
\end{abstract}

Keywords: handicraft, written batik, Lasem 


\section{Pendahuluan}

Seni kerajinan batik tulis Lasem merupakan salah satu identitas dari kota Rembang. Proses terciptanya batik tulis Lasem tidak terlepas dari peran etnis Tionghoa generasi awal yang datang mendarat di sepanjang pantai Bonang - Lasem, bernama Bi Nang Un. la adalah salah satu nahkoda kapal dari rombongan Laksamana Cheng Ho dari Campa pada masa Dinasti Ming. Unjiya (2014) berpendapat bahwa Bi Nang Un tertarik dengan pulau Jawa (Lasem) yang gemah ripah loh jinawe, lalu memohon izin kepada Pangeran Wijaya Badra (Adipati Lasem) yang berkuasa di Lasem pada tahun 1413, untuk diperbolehkan menetap dan membawa sanak keluarganya datang dan hidup di Lasem. Permohonan tersebut dikabulkan dengan memberikan tempat tinggal untuk Bi Nang Un dan keluarganya di luar belakang pagar Istana Kriyan, di kampung Kemandhung (sebelah selatan kali/kanal jembatan mendung) yang kemudian disebut "taman banjar mlathi".

$\mathrm{Bi}$ Nang Un bersama dengan istrinya, $\mathrm{Na} \mathrm{Li} \mathrm{Ni}$, memilih tinggal di Lasem selain dikarenakan melihat keindahan alam Jawa, juga untuk menyebarkan Agama Islam kepada penduduk pribumi setempat. Selain itu, Na Li Ni merupakan wanita yang memiliki bakat seni, salah satunya seni batik. la mengajarkan keahlian seninya, khususnya seni batik kepada para gadis pribumi Lasem dan kepada anak-anaknya, terutama putrinya, Bi Nang Ti. Hal tersebut terdapat dalam penggalan isi naskah Carita Sejarah Lasem (Babad Lasem) yang ditulis oleh Empu santhi Badra (1401 Saka / 1479 M) dan telah digubah oleh Raden Panji Kamzah tahun 1787 saka / 1858 M. Penggalan naskah yang dimaksud yaitu, "Neng Taman Banjar Mlathi kono Putri Na Li Ni mulang nggawe slepi lar merak, mbathik, lan mulang njoged maring bocahbocah wedok Kemandhung, lan uga mulang marang putra putine dhewe". Setelah dewasa, $\mathrm{Bi}$ Nang Ti mengembangkan seni batik tersebut dan menularkan keahliannya kepada temantemannya hingga akhirnya berkembang dan muncul pengusaha-pengusaha batik tulis Lasem keturunan Tionghoa, dengan melibatkan pribumi Lasem dan sekitarnya sebagai buruh batik tulis. Hal tersebut sejalan pendapat Musman, Arini, and Kenyar $(2011,63)$ bahwa, "Pada masa kejayaan batik tulis Lasem setiap rumah tinggal orang Tionghoa mengusahakan pembatikan dengan merekrut tenaga pembatik dari desa sekitar Lasem". Pribumi tersebut berbondongbondong menjadi buruh batik dengan ikut juragan keturunan Tionghoa dengan upah seadanya. Kesempatan tersebut tidak disia-siakan olehnya karena selain meningkatkan perekonomian keluarga, juga untuk menyerap pengetahuan membatik yang sebelumnya tidak diketahuinya.

Keterampilan pribumi dalam membatik semakin berkembang luas. Para buruh batik tersebut pada akhirmya mampu untuk menciptakan motif batik Lasem yang berselerakan pribumi, dimana motif-motif tersebut banyak terinspirasi dari objek di lingkungan sekitar Lasem, seperti motif gunung ringgit, latohan, pasiran / tanahan, krecak / watu pecah, dan yang lain. Berkaitan dengan pernyataan tersebut, Unjiya $(2014,9)$ berpendapat bahwa, "Batik Lasem membuat perajin menjadi semakin kreatif. Motif baru, seperti latohan, gunung ringgit, kricakan atau watu pecah bermunculan".

Selain batik berselerakan pribumi tersebut, terdapat juga batik tulis Lasem berselerakan Tionghoa yang sangat dipengaruhi oleh kebudayaan Cina. Unjiya (2014) berpendapat bahwa $\mathrm{Na}$ Li Ni mulai membatik bermotifkan burung hong, liong, bunga seruni, banji, mata uang, dan motif-motif khas Tionghoa lainnya, hingga akhirnya motif-motif tersebut menjadi ciri khas dan keunikan batik tulis Lasem untuk diperkenalkan kepada perajin batik pribumi setempat. Kemudian, Musman, Arini, and Kenyar (2011) juga berpendapat bahwa pengaruh budaya Jawa (keraton) juga ikut mewarnai corak, motif dan ragam hias batik tulis Lasem, yaitu terbukti dengan adanya motif-motif seperti kawung dan parang. 
Keunikan dan kekhasan tersebut menjadikan batik tulis Lasem sebagai seni kerajinan yang indah dan bernilai ekonomi tinggi. Namun, industri batik tulis di Lasem sulit berkembang dikarenakan juragan batik keturunan Tionghoa yang enggan untuk menularkan ilmunya kepada generasi muda yang bukan garis keturunannya. Mereka memegang teguh tradisi bahwa rahasia dalam dunia perbatikan tidak boleh ditularkan kepada orang lain. Oleh karena itu, masalah pokok yang berusaha dikaji adalah "Bentuk Seni Kerajinan Batik Tulis Lasem di Perusahaan Batik Tulis Lasem Sekar Kencana Di Desa Babagan Kecamatan Lasem Kabupaten Rembang". Berdasarkan masalah pokok tersebut, diajukan pertanyaan penelitian, yaitu: Bagaimana bentuk seni kerajinan batik tulis Lasem motif krecak di perusahaan batik tulis Lasem Sekar Kencana di Desa Babagan Kecamatan Lasem Kabupaten Rembang?.

\section{Metode}

Penelitian ini menggunakan pendekatan kualitatif, dengan metode untuk pengumpulan data adalah metode wawancara, observasi, dan dokumentasi. Validitas penelitian menggunakan teknik triangulasi dan model analisis yang digunakan dalam penelitian adalah model analisis mengalir (flow model of analysis) oleh Miles and Huberman (1992, 20). Penelitian ini dilakukan di perusahaan batik tulis Lasem Sekar Kencana di Desa Babagan Kecamatan Lasem Kabupaten Rembang.

\section{Hasil dan Pembahasan}

\section{Deskripsi Lokasi Penelitian}

\section{Desa Babagan sebagai Desa Wisata Batik Tulis Lasem}

Lasem adalah nama salah satu kota kecamatan di Kabupaten Rembang. Aziz $(2014,68)$ dalam bukunya yang berjudul "Lasem Kota Tiongkok Kecil" memberi catatan bahwa pada zaman kolonial, status kota Lasem adalah sebuah kota kabupaten, tetapi sejak tahun 1750 kota kabupaten dipindahkan ke Rembang, yang diikuti dengan pindahnya benteng VOC dari kota tersebut pada tahun itu. Sehingga, tercatat sejak tahun 1751 sampai sekarang (2021), Lasem berstatus sebagai kota kecamatan.

Kecamatan Lasem merupakan lokasi yang cukup strategis dan menguntungkan, dikarenakan terletak di jalur Pantai Utara (Pantura) antara Semarang dan Surabaya yang menyebabkan kota Lasem sebagai pusat perdangangan yang tidak pernah sepi. Sejalan dengan hal tersebut, Aziz $(2014,68)$ turut berpendapat bahwa sebagai sebuah kota di pesisir utara Jawa, Lasem dikenal sebagai kota bandar yang penting pada masa kolonial dikarenakan di sana lah lalu lintas perdagangan berlangsung dengan menghubungkan antara beberapa kota bandar di Jawa, terutama kota-kota di pedalaman, yang menyebabkan Lasem menjadi simpul perdagangan kota pesisir, di samping Jepara, Tuban, dan Gresik. 


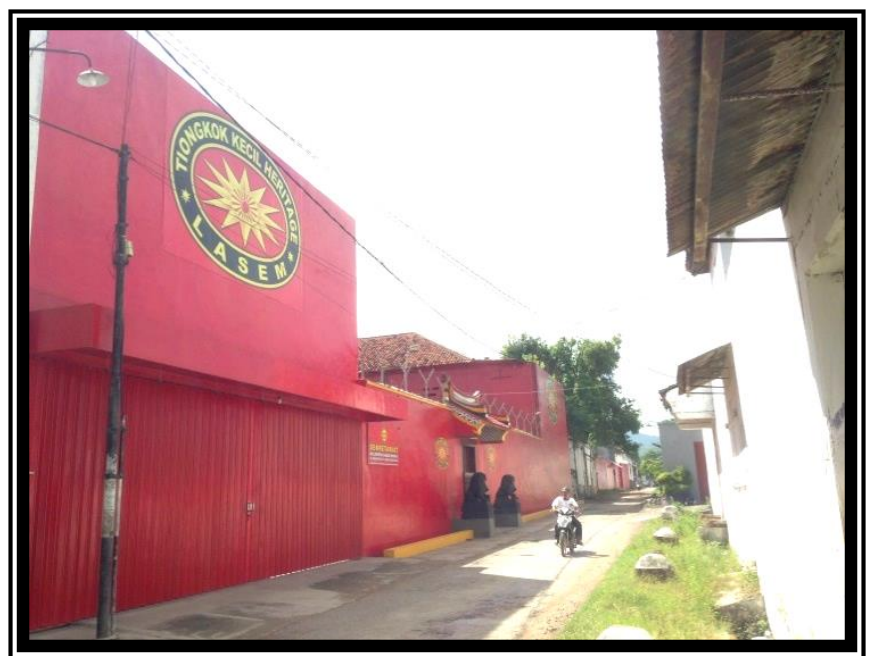

Gambar 1 Suasana di Salah Satu Sudut Jalan di Kota Lasem (Dokumentasi: Qisthi Maghfiroh)

Industri-industri yang berkembang di Lasem di antaranya: batik tulis, garam, krupuk, pengolahan ikan, pengolahan kayu, penggilingan batu, sirup dan limun kawis, batu bata, dan yang lain. Namun, di antara industri-industri tersebut yang paling mengalami perkembangan pesat adalah industri batik tulis. Lasem sebagai kawasan industri batik tulis juga dikenal dengan sebutan "Tiongkok Kecil". Aziz $(2014,39)$ dalam bukunya berpendapat bahwa Lasem juga dikenal sebagai "le petit chinoise" (the little China) atau Tiongkok Kecil dikarenakan model arsitektur, suasana kehidupan, dan interaksi penduduk Tionghoa peranakan yang begitu lekat. Sejalan dengan julukan Tiongkok Kecil tersebut, Unjiva $(2014,6)$ juga memaparkan pendapatnya sebagai berikut:

Lasem disebut oleh peneliti Perancis sebagai Petit Chinois (Tiongkok Kecil) atau disebut The Little Beijing Old Town oleh sejarawan Eropa di masa kolonial. Menurutnya, banyaknya peninggalan berupa kebudayaan yang mempunyai nilai unifikasi tersendiri sebagai warisan budaya yang unik dan mencerminkan multi-kultur yang kuat, terutama antara kebudayaan Jawa dan Cina.

Selain berada di kota Lasem itu sendiri, batik tulis Lasem juga dapat ditemui di sekitar kota Lasem, seperti di Kecamatan Pancur dan Pamotan. Masing-masing daerah tersebut mempunyai keunikan batik tulis yang tidak sama yang disebabkan oleh keluwesan tangan, kreativitas perajin batik, dan faktor lingkungan sekitar yang mempunyai ciri khas tersendiri.

Di kota Lasem, desa yang menjadi sentra industri batik tulis terbesar adalah Desa Babagan. Desa Babagan menjadi Desa Wisata Batik Tulis Lasem sejak 17 Juli 2014, yang diresmikan langsung oleh Menteri Pariwisata dan Ekonomi Kreatif Republik Indonesia yang menjabat pada saat itu, Mari Elka Pangestu. Acara peresmian tersebut dihadiri juga oleh Bupati Kabupaten Rembang yang menjabat pada saat itu beserta jajarannya, dinas - dinas terkait, Kepala Desa Babagan beserta jajarannya, pengusaha-pengusaha batik tulis dan para pembatik di Desa Babagan, dan yang lain. 


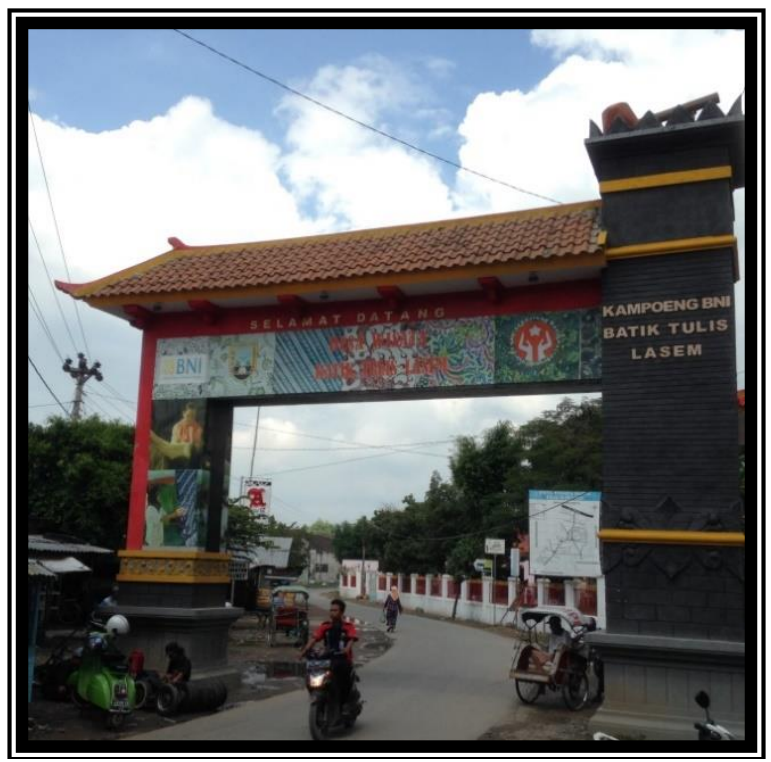

Gambar 2 Gapura Masuk Desa Babagan

(Dokumentasi: Qisthi Maghfiroh)

Desa Babagan di Kecamatan Lasem Kabupaten Rembang terdapat sebanyak 15 perusahaan batik tulis yang aktif berproduksi dan telah mendaftarkan merk dagang perusahaannya, serta telah mendapat ijin resmi dari Pemerintah Kota Rembang, yaitu: (1) Batik Tulis Sekar Kencana; (2) Batik Tulis Padie Boeloe; (3) Batik Tulis Katrin's Bee; (4) Batik Tulis Kidang Mas; (5) Batik Tulis Burung Sriti; (6) Batik Tulis Dua Putri; (7) Batik Tulis Maju Jaya; (8) Batik Tulis Asri Ana Budaya; (9) Batik Tulis Laksam; (10) Batik Tulis Talenta; (11) Batik Tulis Sekar Mulyo; (12) Batik Tulis Agsa; (13) Batik Tulis Bima Art's; (14) Batik Tulis Sumber Rejeki; (15) dan Batik Tulis Dewi Sinta.

\section{Perusahaan Batik Tulis Lasem Sekar Kencana}

Perusahaan Batik Tulis Lasem Sekar Kencana beralamatkan di Jalan Babagan Gang IV, Nomor 4, Desa Babagan Kecamatan Lasem Kabupaten Rembang, yaitu berjarak sekitar 250 meter dari gapura masuk Desa Wisata Batik Tulis Lasem. Pemilik perusahaan batik tulis Sekar Kencana merupakan seorang Hoakiao (sebutan untuk keturunan Cina perantauan) yang telah lama atau sebagai pewaris yang paling lama menggeluti usaha kerajinan batik tulis Lasem, yaitu Sigit Witjaksono.

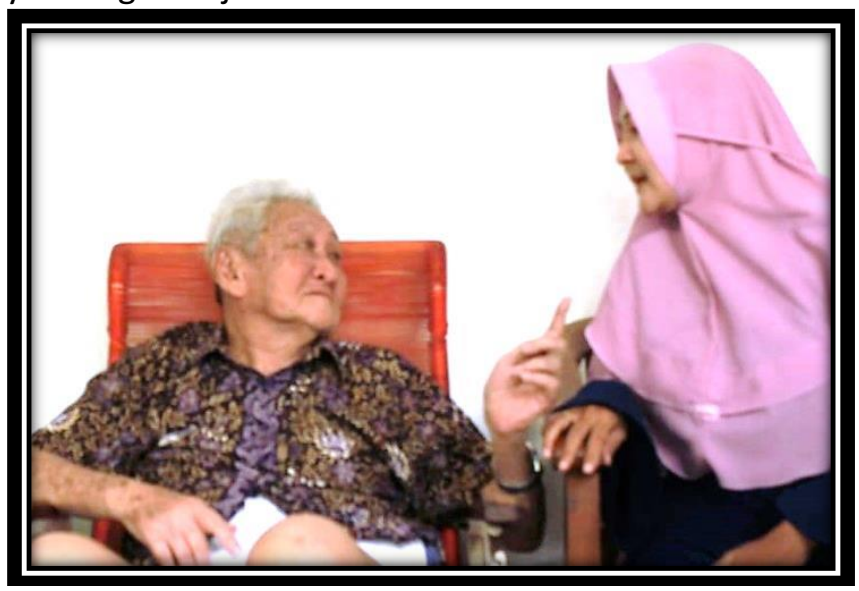

Gambar 3 Sigit Witjaksono dengan Penulis

(Sumber: Dokumentasi Pribadi Penulis) 
Perusahaan batik tulis Lasem Sekar Kencana tidak memiliki toko / showroom yang berada di Desa Babagan. Hasil produksi kain batik tulisnya disimpan dan di-display di rumah produksi yang juga merupakan kediaman pribadi juragan. Rumah produksi batik tulis tersebut sangat mudah ditemukan dikarenakan bergaya khas rumah Tiongkok dengan pagar tembok menjulang tinggi, yang merupakan warisan dari leluhurnya secara turun temurun. Berkaitan dengan workshop perusahaan batik tulis Lasem Sekar Kencana yang merupakan warisan dari leluhurnya secara turun temurun tersebut, Pratiwo dalam Aziz $(2014,52)$ berpendapat bahwa, "Pemukiman orang Tionghoa di Lasem pada awalnya berada di Dasun, kemudian berkembang ke Babagan, hingga meluas ke Karangturi, di tengah kota Lasem pada abad XVIII".

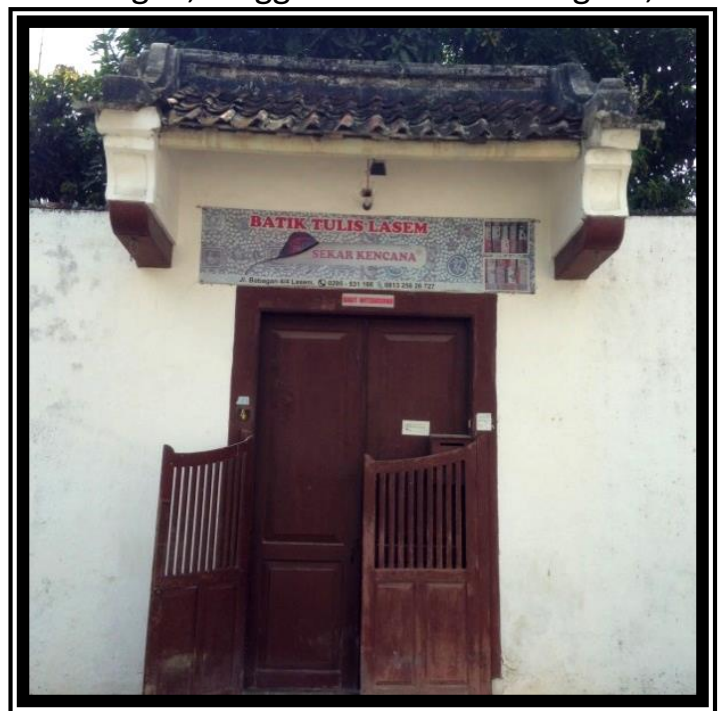

Gambar 4 Rumah Produksi Perusahaan Batik Tulis Lasem Sekar Kencana (Dokumentasi: Qisthi Maghfiroh)

\section{Deskripsi Hasil Penelitian dan Pembahasan}

Bentuk seni kerajinan batik tulis Lasem yang diproduksi di perusahaan batik tulis Lasem Sekar Kencana mempunyai keunikan dan ciri khas tersendiri dibandingkan dengan produk kain batik tulis Lasem lainnya. Hal tersebut dikarenakan Sigit Witjaksono selaku pemilik usaha, tetap berusaha mempertahankan sejarah bahwa motif batik tulis Lasem merupakan produk silang budaya antara Jawa dan Cina. Unjiya $(2014,8)$ berpendapat bahwa:

Konon, perkembangan batik Lasem dipengaruhi oleh unsur seni dan budaya negeri seberang, yaitu orang-orang dari negeri Cina dan Campa yang datang ke Lasem dan membaur dengan penduduk lokal yang lambat laun melahirkan akulturasi budaya yang positif dan kaya, di antaranya adalah seni "batik Laseman" itu sendiri.

Motif batik yang terpengaruh budaya Cina dapat terlihat dari penggunaan ornamenornamen seperti burung hong, banji, naga, bunga seruni, bunga teratai, kura-kura, merak, dan yang lain. Pengusaha batik tulis Lasem, terutama keturunan Cina, telah menggunakan motifmotif khas kebudayaan Cina tersebut sejak dahulu, dimana motif-motif tersebut diperkenalkan oleh keturunan Cina yang datang ke Lasem. Berkaitan dengan hal tersebut, Kusrianto (2013, 224) berpendapat bahwa, "Batik Lasem diperkirakan mulai diproduksi sejak tahun 1415 yang dikenalkan oleh Putri Na Li Ni dari Campa". Selain itu, Unjiya $(2014,8)$ juga berpendapat bahwa, "( . . ) Na Li Ni mulai membatik bermotifkan burung hong, liong, bunga seruni, banji, mata uang, dan warna merah darah ayam khas Tionghoa. Motif ini kemudian menjadi ciri khas dan keunikan batik Lasem".

Sedangkan, motif yang terpengaruh budaya Jawa dapat terlihat dari motif geometris khas keraton, seperti parang, kawung, dan yang lain. Selain itu, para perajin batik di Lasem dan 
sekitarnya juga menciptakan motif lokal sendiri yang terinspirasi dari sejarah dan lingkungan alam sekitar Lasem, seperti gunung ringgit, krecak / watu pecah, latohan, sekar jagad laseman, pasiran / tanahan, dan yang lain. Unjiya $(2014,9)$ berpendapat bahwa, "Batik Lasem membuat perajin menjadi semakin kreatif. Motif baru, seperti latohan, gunung ringgit, kricakan atau watu pecah bermunculan". Di antara motif-motif khas Lasem tersebut, motif latohan dan motif krecak / watu pecah dianggap oleh masyarakat Lasem dan sekitarnya memiliki keunikan dan kekhasan tersendiri. Kusrianto $(2013,224)$ memaparkan pendapatnya sebagai berikut:

Batik Lasem setidaknya mempunyai dua corak khas, yaitu Latohan dan Krecak / Watu Pecah. Motif Latohan diangkat dari tanaman sejenis rumput laut (ganggang) yang menjadi makanan khas masyarakat Lasem. Sementara motif Krecak atau Watu Pecah adalah kenangan yang menyakitkan atas peristiwa kerja paksa masyarakat Lasem sewaktu pembuatan jalan Daendeles yang memakan banyak korban.

Sejalan dengan pendapat tersebut, Sigit Witjaksono juga mengemukakan bahwa terdapat tiga motif batik tulis khas Lasem, yaitu latohan, sekar jagad, dan watu pecah / krecak (Hasil wawancara dengan Sigit Witjaksono, 11 Januari 2019). Berdasar pada pendapatpendapat tersebut, maka batik tulis Lasem motif krecak dipilih untuk dijadikan sample penelitian di perusahaan batik tulis Lasem Sekar Kencana Desa Babagan Kecamatan Lasem Kabuparen Rembang dikarenakan motif tersebut merupakan salah satu motif yang dihasilkan dari kreativitas pembatik-pembatik pribumi Lasem yang memiliki keunikan dari segi bentuk dan sumber ide di balik penciptaan motif tersebut.

Dalam pembuatan desain gambar / motif batik krecak, dilakukan sendiri oleh Sigit Witjaksono, untuk kemudian akan dipola oleh karyawannya. Selain itu, ia juga melakukan inovasi atau terobosan baru, yaitu dengan memadu padankan motif khas Lasem, misalnya motif krecak / watu pecah, latohan, sekar jagad laseman, dan yang lain, dengan tulisan / aksara Tionghoa yang mengandung harapan atau doa. Ide penciptaan motif baru (aksara Tionghoa) tersebut ia dapatkan pada saat perenungannya di malam tahun baru Cina. Tambahan ornamen-ornamen khas Cina lainnya pun selalu ditampilkan, seperti burung hong, kura-kura, merak, kupu-kupu, dan yang lain. Hal tersebut dilakukannya agar akulturasi budaya setempat (Lasem) dan Cina yang dituangkan dalam seni kerajinan batik tulis Lasem, dapat diterima oleh masyarakat luas dan dapat dikembangkan lagi motifnya oleh pengusaha batik tulis Lasem lainnya. Hal tersebut sesuai pernyataan Sigit Witjaksono, yaitu "Agar akulturasi budaya antara Lasem dan Cina bisa diterima oleh masyarakat umum dan bisa dikembangkan lagi" (Hasil wawancara dengan Sigit Witjaksono, 11 Januari 2019). Selain itu, ia juga menambahkan bahwa, "Saya ingin membuktikan bahwa batik tulis Lasem memang akulturasi dari budaya Jawa dan Cina seperti sejarahnya" (Hasil wawancara dengan Sigit Witjaksono, 11 Januari 2019).

Usaha yang dilakukan olehnya tersebut pun membuahkan hasil. Saat ini mulai bermunculan beberapa pengusaha batik tulis Lasem keturunan Tionghoa yang juga mengimbuhkan aksara Tionghoa ke dalam motif batik tulisnya. Akan tetapi, gaya / corak dan makna yang tersirat dalam tulisan Tionghoa tersebut tidak boleh sama dengan apa yang telah diciptakan oleh Sigit Witjaksono. Sebagai antisipasi agar konsumen tidak salah pilih dalam membeli produk kain batik tulis Lasem produksi perusahaan batik tulis Lasem Sekar Kencana, Sigit Witjaksono berinisiatif untuk mengimbuhkan namanya yang di-canthing di pojok kiri bawah kain sebagai identitas produk batik tulis miliknya. 


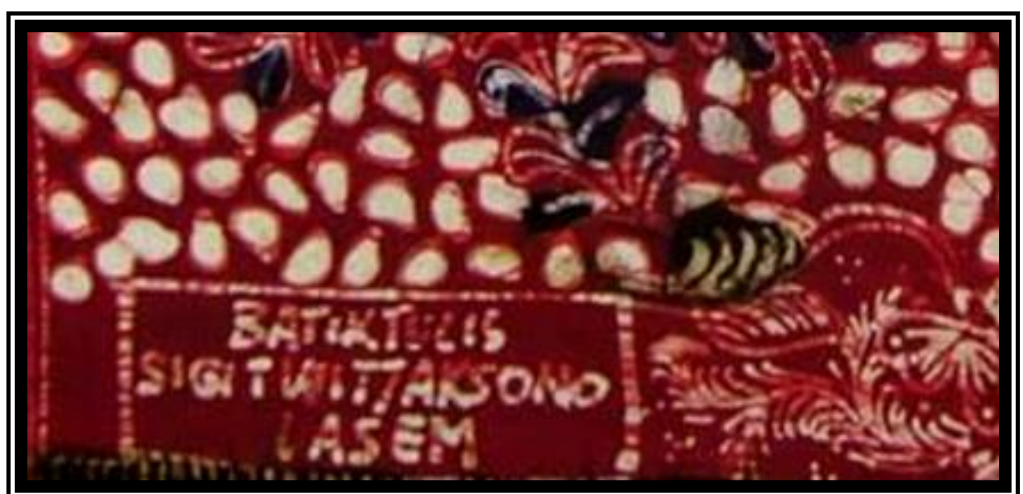

Gambar 5 Identitas Nama Sigit Witjaksono Pada Produk Kain Batik Tulis Lasem Motif Krecak di Perusahaan Batik Tulis Lasem Sekar Kencana

(Dokumentasi: Qisthi Maghfiroh)

Tiru-meniru motif dan warna memang sudah menjadi hal yang wajar di industri batik tulis Lasem. Jika satu perusahaan batik mampu menciptakan motif batik tulis Lasem yang laris di pasaran, maka para perajin batik lainnya pun berlomba-lomba untuk meniru motif tersebut semirip mungkin, yang dikerjakan di perusahaannya masing-masing. Berkaitan dengan tirumeniru tersebut, Sumarsono et al. $(2013,70)$ berpendapat bahwa:

Tiru-meniru desain, teknik, warna, dan sebagainya terjadi dimana-mana. Tidak heran kalau tempat pembatikan banyak yang dikelilingi tembok tinggi seperti di Lasem maupun di Laweyan di Solo. Ini cuma salah satu usaha untuk melindungi rahasia mereka dari pesaing.

Sebagai pengusaha batik tulis Lasem, Sigit Witjaksono tergolong idealis. Hal tersebut dikarenakan ia enggan untuk memasukkan unsur-unsur modern dalam pewarnaan batik tulisnya, seperti yang dilakukan para pengusaha batik tulis Lasem lainnya yang menggunakan warna pink, toska, magenta, dan yang lain. Sigit Witjaksono berpendapat sebagai berikut, "Batik tulis yang saya produksi memang tidak dicampur dengan gaya pekalongan atau gaya modern yang lain, karena saya lebih senang dengan yang klasik" (Hasil wawancara dengan Sigit Witjaksono, 11 Januari 2019). Oleh sebab itu, produk kain batik tulisnya tetap mempertahankan warna-warna klasik khas Lasem, seperti soga, merah, biru, ungu, dan hijau. Berikut adalah keunikan dan kekhasan batik tulis Lasem yang diproduksi di perusahaan batik tulis Lasem Sekar Kencana.

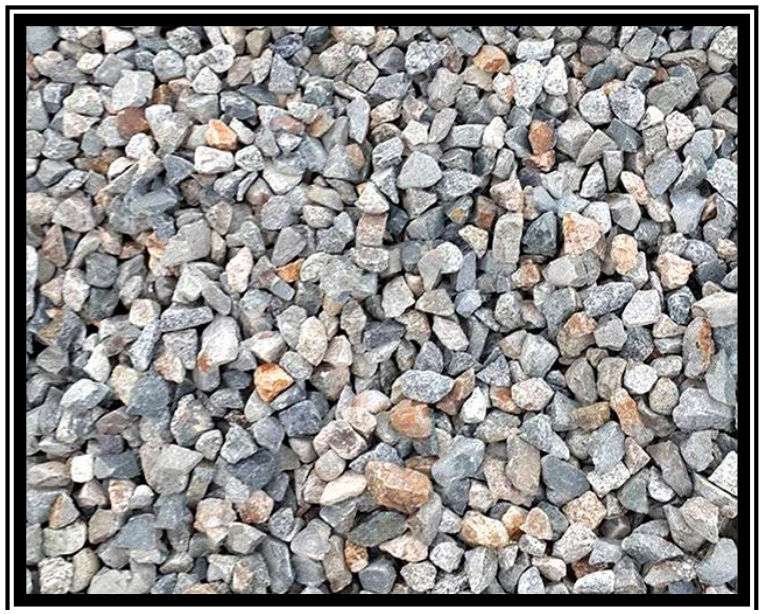

Gambar 6 Krecak sebagai Bahan Pembuatan Jalan Yang Dijadikan Inspirasi Penciptaan Motif Krecak (Dokumentasi: Qisthi Maghfiroh) 


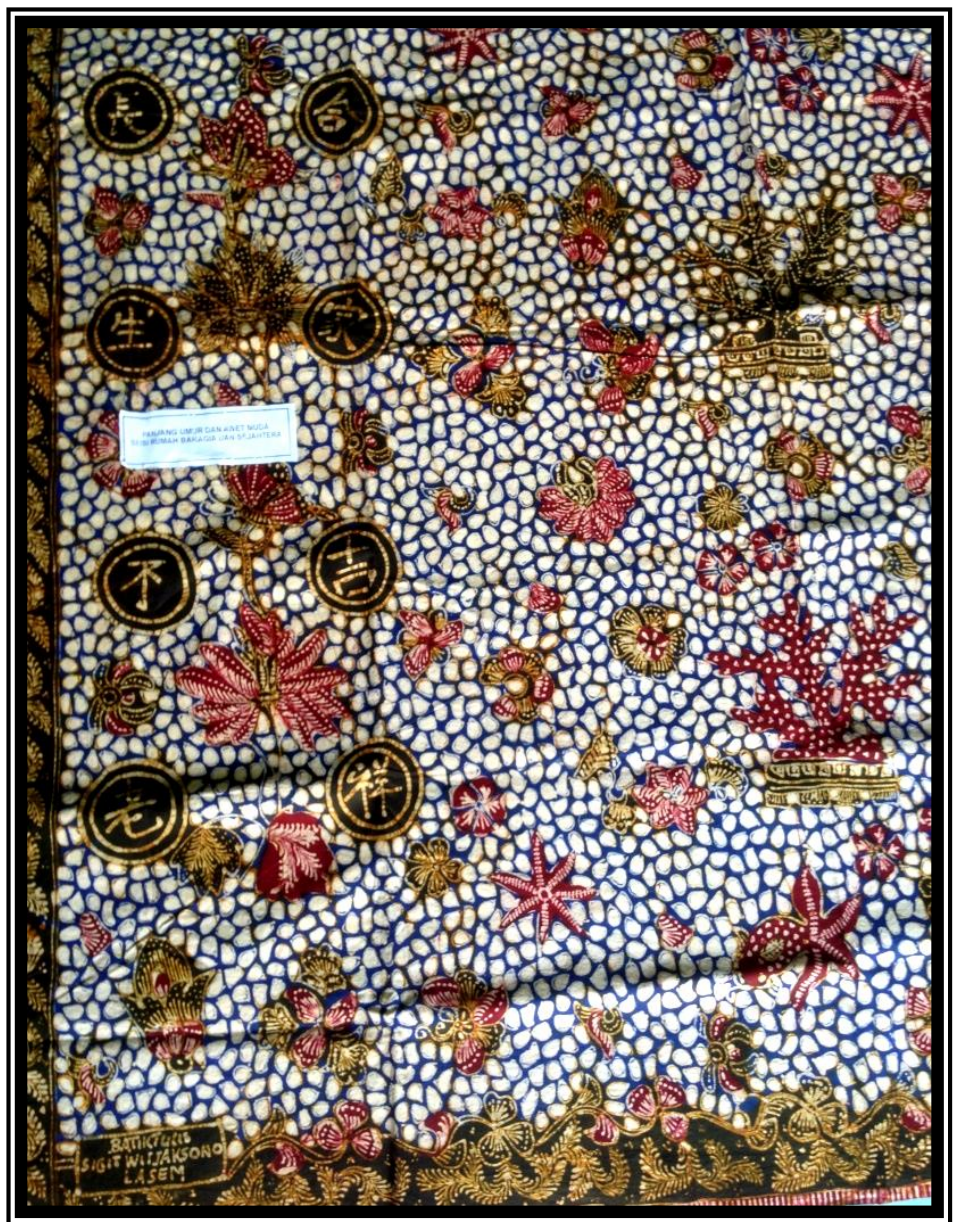

Gambar 7 Batik Tulis Lasem Motif Krecak di Perusahaan Batik Tulis Lasem Sekar Kencana (Dokumentasi: Qisthi Maghfiroh)

\section{Sumber Ide Penciptaan Motif}

Motif krecak/watu pecah merupakan ekspresi kejengkelan warga masyarakat Lasem terhadap proyek Daendles, yaitu pembangunan Jalan Raya Pos yang banyak menelan korban jiwa pada saat itu. Hal tersebut menjadi inspirasi bagi desainer batik atau perajin batik (pembatik) dalam menciptakan desain motif batik Lasem yang khas.

Pada motif krecak / watu pecah ini, Sigit Witjaksono mempertahankan bahwa batik tulis Lasem adalah pembauran antara budaya setempat (Lasem) dan Cina. Berkaitan dengan hal tersebut, Musman, Arini, and Kenyar (2011, 62-63) berpendapat bahwa, "Kekhasan lain batik Lasem ini terletak pada coraknya yang merupakan gabungan pengaruh budaya Tionghoa, budaya lokal masyarakat pesisir utara Jawa Tengah serta budaya Keraton Solo dan Yogyakarta". Selain itu, warna-warna yang dipilih konsisten menggunakan warna-warna klasik Lasem, seperti merah, biru, dan soga. Desain gambarnya pun dibuat sendiri olehnya, sehingga corak yang terdapat pada motif krecak / watu pecah tersebut tidak akan ditemui di tempat lainnya.

Pengaruh budaya Jawa, khususnya budaya lokal masyarakat di Lasem, dalam motif ini tampak pada penggunaan ornamen-ornamen yang terinspirasi dari lingkungan alam sekitar Lasem, seperti ornamen utama krecak / watu pecah dan ornamen tambahan seperti bintang laut, karang laut, dan gurita. Sedangkan pengaruh kebudayaan Cina dituangkan dalam ornamen tambahan, seperti aksara Tionghoa, kupu-kupu, bunga seruni, dan laba-laba. Aksara Tionghoa tersebut merupakan inovasi atau terobosan baru yang diciptakan oleh Sigit Witjaksono agar masyarakat mengingat sejarah dan dapat menerima bahwa batik tulis Lasem 
merupakan akulturasi antara kebudayaan Cina dan Jawa. Dalam sample motif krecak / watu pecah tersebut, Sigit Witjaksono mengimbuhkan aksa Tionghoa yang artinya "Panjang Umur Dan Awet Muda, Seisi Rumah Bahagia Dan Sejahtera".

\section{Analisis Struktur Desain Berdasarkan Unsur-unsur Ornamen Motif dan Penyusun Ornamennya}

Motif batik menurut unsurnya berdasarkan pendapat dari Susanto (1973) dibagi menjadi dua yaitu ornamen motif batik dan isen-isen motif batik. Ornamen batik dibagi menjadi ornamen utama dan ornamen tambahan.

Motif krecak/watu pecah memiliki latar penuh dengan ornamen krecak atau pecahan kecil dari batu yang merupakan ekspresi dari perajin (pembatik) Lasem dalam suatu peristiwa yang menelan banyak korban jiwa. Untuk pola krecak/watu pecah seluruhnya terdiri dari ornamen-ornamen pecahan kecil dari batu (krecak) yang berbentuk tidak beraturan yang disusun menyebar pada latar batik, yang dipadu padankan dengan motif tambahan seperti aksara Tionghoa, bunga seruni, kupu-kupu, laba-laba, bintang laut, gurita, terumbu karang, dan bunga. Sedangkan isen-isen yang dipakai dalam motif ini yaitu cecek-cecek dan sawut yang digunakan untuk mengisi dan mempercantik ornamen tambahan.

Berdasarkan teori penyusunan ornamen, Budiyono et al. (2008) berpendapat bahwa penyusunan ornamen pada motif batik krecak/watu pecah tersebut menggunakan gabungan antara teknik random, transisi, dan repetisi. Untuk membentuk ornamen utama, satu pola ornamen utama tersebut disusun berulang kali dengan teknik transisi arah dan ukuran karena mengalami pengulangan disertai perubahan-perubahan dekat pada arah dan ukuran ornamennya secara terus-menerus memenuhi latar kain batik. Kemudian, pada ornamen tambahan seperti daun, bunga, laba-laba, bintang laut, dan gurita, menggunakan teknik random karena disusun secara acak tanpa ada ikatan pola tertentu, sehingga beberapa pola ditempatkan secara menyebar bebas di seluruh permukaan kain batik tulis. Di sisi lain, untuk ornamen tambahan kupu-kupu, bunga seruni, aksara Tionghoa, dan karang laut, masingmasing mengalami pengulangan dengan kesamaan ekstrem pada bentuk, raut, ukuran, arah, warna, tekstur, dan jarak.

\section{Analisis Struktur Desain Berdasarkan Unsur-unsur Seni Rupa}

1. Bentuk

Sanyoto (2010) berpendapat bahwa benda apa saja di alam semesta ini, termasuk karya seni/desain tentu mempunyai bentuk (form), dan bentuk tersebut dapat disederhanakan lagi menjadi titik (spot), garis, bidang (shape), dan gempal (volume). Benda yang dapat disederhanakan ke dalam kategori titik (spot) dalam motif batik watu pecah ini adalah berupa cecek-cecek untuk mengisi atau mempercantik ornamen tambahan.

Selain itu, benda-benda yang dapat dikategorikan sebagai garis dalam motif batik ini yaitu berupa garis baik garis lurus maupun garis lengkung. Garis lurus dipergunakan untuk membentuk isen sawut pada ornamen tambahan. Sedangkan garis lengkung dipergunakan sebagai outline pembentuk ornamen utama dan tambahan.

Kemudian, benda-benda yang dapat disederhanakan sebagai bidang (shape) pada motif watu pecah ini yaitu ornamen utama krecak/watu pecah dan ornamen tambahan. Sedangkan benda-benda yang mempunyai dimensi panjang, lebar, dan tinggi yang dapat disederhanakan ke dalam kategori gempal (volume), tidak dapat ditemukan pada kain batik tulis yang hanya mempunyai dimensi panjang dan lebar saja.

2. Raut

Raut merupakan ciri khas yang dimiliki oleh setiap benda yang membedakan masingmasing bentuk dari titik (spot), garis, bidang (shape), dan gempal (volume). Sanyoto (2010, 83) berpendapat bahwa, "Bentuk apa saja di alam ini tentu memiliki raut yang merupakan 
ciri khas dari bentuk tersebut". Dari pernyataan tersebut dapat disimpulkan bahwa bentuk titik (spot), garis, bidang (shape), dan gempal (volume), masing-masing tentu memiliki raut.

Pada motif krecak ini, raut titik tergantung pada canthing yang digunakan, yaitu besar kecil lubang carat/cucuk dari canthing yang dipergunakan, dan pada kecepatan tangan perajin dalam menggoreskan canting yang berisi malam panas di atas permukaan kain batik. Karena semakin cepat gerak tangan perajin, maka raut titik yang dihasilkan tidak dapat bundar sederhana, namun elips. Pada motif ini, raut titik yang dihasilkan oleh perajin batik adalah bundar sederhana.

Kemudian, untuk raut garis pada motif krecak ini yaitu lurus dan lengkung, dengan mengikuti arah dari garis tersebut. Untuk motif ini sendiri dapat dikategorikan sebagai gabungan bidang geometri dan non geometri. Hal tersebut dapat terlihat dari ornamen tambahan aksara Tionghoa, kupu-kupu, bunga seruni, dan terumbu karang yang disusun berulang di beberapa sudut kain batik.

Kemudian, ornamen tambahan lainnya seperti bunga, daun, laba-laba, dan gurita memiliki raut bidang organik, yaitu bidang-bidang yang dibatasi garis lengkung bebas. Di sisi lain, ornamen utama watu pecah disusun secara transisi dengan perubahan-perubahan dekat pada ukuran dan arah ornamen, yang menyebar di seluruh latar kain batik. Namun dalam motif batik tulis Lasem ini, tidak dapat ditemukan raut gempal.

3. Ukuran

Ukuran yaitu berupa besar, kecil, tinggi, rendah, panjang, pendek, tebal, dan tipis. Namun, ukuran yang dimaksudkan bukan dalam besaran sentimeter atau meter, tetapi ukuran yang bersifat nisbi yaitu bersifat relatif atau disesuaikan dengan bentuk tersebut berada. Dari pernyataan tersebut, Wahida and Handayani $(2002,24)$ menambahkan, "Apabila ukurannya tidak seimbang maka desain yang dihasilkan akan kelihatan kurang baik". Sehingga ukuran merupakan unsur yang diperhitungkan dalam seni rupa dan desain, dengan memperhitungkan ukuran menurut perspektif seni rupa, maka akan diperoleh hasil-hasil keindahan tertentu.

Untuk motif batik tulis krecak ini, benda-benda yang mempunyai ukuran yaitu garis dan bidang. Panjang, tinggi, dan besarnya garis tersebut dipengaruhi oleh ruang di mana garis tersebut berada. Ukuran panjang garis untuk outline pada ornamen utama dan ornamen tambahan, masing-masing menyesuaikan dari visualisasi bentuknya. Sedangkan panjang garis untuk isen sawut pada ornamen tambahan tergantung pada luas bidangnya. Dan untuk ukuran tinggi garis, masing-masing menyesuaikan dari bidang ornamen tersebut. Kemudian, ketebalan dari garis dipengaruhi oleh ukuran dari cucuk/carat canthing yang digunakan dan kecepatan tangan oleh masing-masing perajin. Untuk keseluruhan garis, baik garis lengkung maupun garis lurus mempunyai ketebalan garis yang sama, terkeculi garis lengkung pembentuk ornamen tambahan aksara Tionghoa yang memiliki ketebalan lebih dibandingkan lainnya.

Bidang pada motif krecak ini pada ornamen utama berukuran sempit, karena diletakkan di area yang sempit dan saling berhimpit, sedangkan bidang pada ornamen tambahan berukuran lebih luas.

4. Arah

Untuk kain batik tulis, bentuk-bentuk yang mempunyai arah terdapat pada bentuk garis dan bidang. Pada motif krecak/watu pecah ini, untuk bentuk garis lurus mempunyai arah diagonal, horisontal, dan vertikal. Sedangkan untuk garis lengkung mempunyai arah kubah, busur, mengapung, dan lengkung S. Kemudian, untuk keseluruhan ornamen utama dan ornamen tambahan mempunyai arah bidang vertikal, horisontal, dan diagonal. 
5. Tekstur

Sanyoto (2010) berpendapat bahwa yang termasuk tekstur semu yaitu tekstur bermotif, bercorak atau bergambar. Sehingga dapat disimpulkan bahwa kain batik tulis mempunyai tekstur semu kasar.

Tekstur kasar semu dapat dikelompokkan lagi menjadi tiga macam, yaitu tekstur manual, tekstur mekanik dan tekstur ekspresi. Maka, kain batik tulis termasuk ke dalam tekstur mekanik, karena pembuatan motifnya melalui pencapan rintang, yaitu malam batik sebagai rintangnya, kemudian baru dicelupkan ke dalam zat warna untuk menghasilkan motif.

Pada motif batik tulis krecak ini, tekstur semu kasar dihadirkan pada ornamen utama yang berukuran kecil dan memenuhi latar kain batik. Sedangkan untuk ornamen tambahan, tekstur semu kasar nampak karena adanya isen-isen sawut dan cecek-cecek.

6. Warna

Warna merupakan salah satu unsur desain yang sangat penting. Karena dengan adanya warna, menjadikan suatu benda dapat dilihat lebih tajam dan menarik. Pada motif batik krecak/watu pecah ini, komposisi warna yang digunakan yaitu:

a. Warna putih, yang berasal dari warna dasar kain mori.

b. Warna merah, yang berasal dari campuran napthol AS-BS dengan garam Red $3 G L$.

c. Warna biru, yang berasal dari campuran napthol $A S$ - dengan garam Blue $B B$.

d. Coklat kekuningan (sogan), yang berasal dari campuran napthol AS-G dengan garam Blue $B$.

e. Warna hitam, yang berasal dari warna hasil campuran napthol $A S$ dengan garam Blue $B B$ yang ditumpuk dengan warna hasil campuran napthol $A S-G$ dengan garam $B / u e B$

7. Ruang

Motif batik tulis krecak ini menempati ruang dua dimensi atau dwimatra. Hal tersebut dikarenakan kain batik hanya memiliki memiliki dimensi panjang dan lebar.

\section{Analisis Struktur Desain Berdasarkan Prinsip-prinssip Dasar Seni Rupa}

1. Irama

Irama adalah gerak pengulangan yang teratur dan terus menerus yang merupakan prinsip yang hakiki pada semua karya seni dan desain untuk mencapai keselarasan. Berdasar visualisasi motif krecak/watu pecah ini, prinsip irama yang digunakan adalah gabungan jenis irama transisi dan irama repetisi. Dalam motif batik ini, irama repetisi terlihat dalam ornamen tambahan aksara Tionghoa, kupu-kupu, bunga seruni, dan karang laut yang disusun berulang dengan kesamaan ketat pada bentuk, ukuran, arah, dan jarak. Sedangkan transisi dihadirkan dalam bentuk ornamen utama yang terdapat pada latar kain batik ini. Transisi pada ornamen utama merupakan pengulangan dengan perubanperubahan dekat pada bentuk dan arah pada motif krecak.

Di sisi lain, ornamen tambahan seperti bintang laut, laba-laba, gurita, daun dan bunga, menempati bidang organis yang disusun secara acak pada latar kain batik tanpa adanya ikatan yang membatasi. Komposisi yang menarik pada ornamen utama maupun ornamen tambahan dalam motif watu pecah ini memberi kesan rapi dan dinamis.

2. Kesatuan

Kesatuan merupakan salah satu prinsip dasar seni rupa. Tanpa adanya kesatuan pada suatu karya seni/desain, maka akan terlihat cerai-berai dan kacau-balau, sehingga tidak menarik dan tidak pas untuk dilihat atau dinikmati. 
Pada motif batik Lasem krecak ini, prinsip kesatuan dapat dicapai dengan pendekatan persamaan warna dan bentuk. Untuk ornamen utama yang berada pada latar kain baik, memiliki kesamaan pada warna yaitu menggunakan warna putih. Selain itu, ornamen ini memiliki kemiripan bentuk dan hanya terjadi perubahan-perubahan dekat dari ukuran dan arah.

Kemudian, pada ornamen tambahan menggunakan warna yang sama yaitu hitam, coklat kekuningan, dan merah. Selain itu, untuk menyatukan ornamen utama dan ornamen tambahan, menggunakan warna yang sama untuk outline, yaitu menggunakan warna coklat kekuningan.

3. Dominasi

Sesuai dari nama motif dari batik tulis ini, yaitu motif watu pecah/krecak, maka prinsip dominasi tercapai dari adanya ornamen utama watu pecah yang memenuhi latar kain batik. Hal tersebut dikarenakan bentuk susunan dominasi tidak bisa hanya satu yang diletakkan pada satu tempat, karena akan mengganggu keseimbangan.

Ornamen utama yang memenuhi latar kain batik berbentuk menyerupai pecahan batu yang berukuran kecil yang disusun berulang dengan perubahan-perubahan dekat dari segi bentuk, arah, dan ukuran, dengan jumlah yang sangat banyak sehingga memberi kesan tekstur semu kasar yang harmonis pada bagian latar kain batik atau background. Hal tersebut kontras dengan ornamen tambahan seperti bunga, daun, bintang laut, laba-laba, dan gurita yang disusun secara oposisi yang diletakkan secara acak dengan pengulangan yang bertentangan pada ukuran dan arah bidang.

4. Keseimbangan

Pada motif batik krecak ini, prinsip keseimbangan yang digunakan adalah keseimbangan asimetris. Hal tersebut dikarenakan jika kain batik ini dibagi dua bagian, maka antara ruang kanan dan kirinya tidak sama persis dalam ukuran dan bentuk tetapi terasa seimbang. Dalam penyusunan asimetris tidak harus memiliki bentuk dan ukuran yang sama, tetapi membutuhkan perasaan yang terlatih untuk menentukan keseimbangan dalam komposisi motif tersebut. Sehingga, akan diperoleh keseimbangan asimetris yang dinamis, bergerak, hidup, bergairah, namun terkesan tidak resmi.

5. Proporsi

Prinsip proporsi dalam motif krecak ini tercapai melalui pemecahan masalah warna dengan menggunakan hukum keluasan. Menurut hukum tersebut, semakin kecil bidang maka menggunakan warna yang kuat, yaitu warna pelangi atau warna yang memiliki unsur hitam. Dan semakin luas area bidang, maka menggunakan warna yang lebih tenang.

Dalam hal ini, area yang lebih sempit terdapat pada ornamen tambahan yang menggunakan warna kuat seperti hitam, merah, dan coklat kekuningan. Selain itu, pada background atau latar kain batik juga mempunyai luas area yang sempit dan menggunakan warna biru. Jadi, area yang lebih luas dalam motif ini adalah bidang-bidang pada ornamen utama dengan warna tenang, yaitu warna putih. Namun, ornamen utama tersebut tidaklah berukuran bidang yang luas, akan tetapi terdiri dari bidang-bidang sempit dengan jumlah yang banyak, sehingga memenuhi latar kain batik atau background. Maka, latar kain batik tersebut akan terlihat seperti area luas dengan warna putih.

6. Kesederhanaan

Pada motif batik krecak ini, prinsip kesederhanaan dapat tercapai karena adanya gabungan jenis irama oposisi pada ornamen tambahan bunga, daun, bintang laut, labalaba, dan gurita, irama repetisi pada ornamen tambahan aksara Tionghoa, bunga seruni, 
kupu-kupu, dan karang laut, serta irama transisi pada ornamen utama watu pecah yang terjadi di seluruh permukaan kain. Sehingga, sudah terlihat pas dan tidak ada yang perlu ditambahi atau dikurangi lagi.

7. Kejelasan

Berdasar visualisasi motif batik krecak ini, prinsip kejelasan dicapai melalui ornamen utama watu pecah yang sudah menjadi fokus yang mudah untuk dimengerti oleh pengamat, walaupun ornamen utama tersebut berukuran kecil tapi dalam jumlah yang banyak dan memenuhi background atau latar kain batik.

\section{Simpulan}

Berdasar pada hasil dan pembahasan tersebut, ditemukan bahwa: Bentuk seni kerajinan batik tulis Lasem motif krecak di perusahaan batik tulis Lasem Sekar Kencana di Desa Babagan Kecamatan Lasem Kabupaten Rembang memiliki keunikan pada motif yang dibuat sendiri oleh juragan dan merupakan akulturasi antara budayaan Cina dengan kebudayaan setempat (Lasem), serta mempertahankan warna-warna klasik khas Lasem dalam batik tulisnya.

\section{Daftar Pustaka}

Aziz, Munawir. 2014. Lasem, kota Tiongkok kecil: interaksi Tionghoa, Arab, dan Jawa dalam silang budaya pesisiran. Yogyakarta: Penerbit Ombak.

Budiyono, Widarwati Sudibyo, Sri Herlina, Sri Handayani, Parjiyah, Wiwik Pudiastuti, Syamsudin, Irawati, Parjiyati, and Dwiyunia Sari Palupi. 2008. Kriya Tekstil untuk SMK Jilid 1. Jakarta: Direktorat Pembinaan Sekolah Menengah Kejuruan, Direktorat Jenderal Manajemen Pendidikan Dasar dan Menengah, Departemen Pendidikan Nasiona.

Kusrianto, Adi. 2013. Batik: filosofi, motif, dan kegunaan. Yogyakarta: Penerbit Andi.

Miles, B. Mathew, and Michael Huberman. 1992. Analisis Data Kualitatif. Jakarta: Universitas Indonesia Press.

Musman, Asti, Ambar B Arini, and Martha Nina Kenyar. 2011. Batik: Warisan Adilihung Nusantara. Yogyakarta: G-Media.

Sanyoto, Sadjiman Ebdi. 2010. Nirmana Elemen-elemen Seni dan Desain. Yogyakarta: Jalasutra.

Sumarsono, Hartono, Helen Ishwara, LR Supriyapto Yahya, and Xenia Moeis. 2013. Benang Raja Menyimpul Keelokan Batik Pesisir. Jakarta: KPG (Kepustakaan Populer Gramedia).

Susanto, SK Sewan. 1973. Seni Kerajinan Batik Indonesia. Balai Penelitian Batik dan Kerajinan, Lembaga Penelitian dan Pendidikan Industri, Departemen Perindustrian RI.

Unjiya, M. Akrom. 2014. Lasem Negeri Dampoawang: Sejarah yang Terlupakan. Yogyakarta: Salma Idea. 
Wahida, A., and E. S. Handayani. 2002. Buku Ajar Pendidikan dan Latihan Profesi Guru (PLPG): Keterampilan. Surakarta: Panitia Sertifikasi Guru (PSG) Rayon 13 FKIP UNS.

Witjaksono, Sigit. Warga Desa Babagan, tokoh Tionghoa di Lasem, pemilik perusahaan batik tulis Lasem Sekar Kencana, 11 Januari 2019

Miles, B. Mathew dan Michael Huberman. 1992. Analisis Data Kualitatif. Jakarta: Universitas Indonesia Press. 